IRA-International Journal of Education \& Multidisciplinary Studies

ISSN 2455-2526; Vol.07, Issue 02 (2017)

Pg. no. 83-88

Institute of Research Advances

http://research-advances.org/index.php/IJEMS

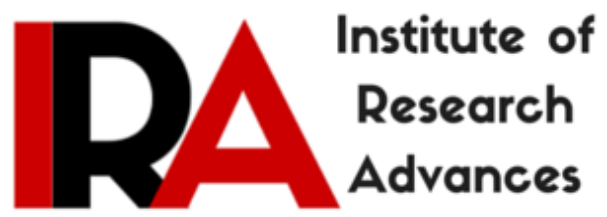

\title{
Attitude of Student Teachers towards Constructivist Approach in Teaching
}

\author{
Susan W Lyngdoh ${ }^{1}$, Prof. S.M Sungoh ${ }^{2}$ \\ ${ }^{1}$ Research Scholar, Department of Education, North Eastern Hill University, \\ Shillong-793022, Meghalaya, India. \\ ${ }^{2}$ Professor, Department of Education,North Eastern Hill University, \\ Shillong-793022, Meghalaya, India.
}

Type of Review: Peer Reviewed.

DOI: http://dx.doi.org/10.21013/jems.v7.n2.p4

\section{How to cite this paper:}

Lyngdoh, S., \& Sungoh, S. (2017). Attitude of Student Teachers towards Constructivist Approach in Teaching. IRA International Journal of Education and Multidisciplinary Studies (ISSN 2455-2526), 7(2), 83-88. doi:http://dx.doi.org/10.21013/jems.v7.n2.p4

(C) Author.

\section{(cc) EY-NO}

This work is licensed under a Creative Commons Attribution-Non Commercial 4.0 International License subject to proper citation to the publication source of the work.

Disclaimer: The scholarly papers as reviewed and published by the Institute of Research Advances (IRA) are the views and opinions of their respective authors and are not the views or opinions of the IRA. The IRA disclaims of any harm or loss caused due to the published content to any party. 


\begin{abstract}
A constructivist approach in teaching is very different from the traditional approach in teaching. It requires the teacher to take upon the role of a guide and a facilitator and encouraging learners to actively participate in the learning process. Attitude of teachers towards this approach will determined the way it will be adopted in classroom teaching and organization. This study aims to find out the attitude of teachers towards constructivist approach in teaching. For this, a Teachers Attitude Scale towards Constructivist Approach in Teaching (TASCAT) was administered to 524 student teachers. Findings reveal that the participants of the study have an unfavourable attitude towards constructivist approach in teaching and there is no significant difference in the attitude towards constructivist approach with respect to gender.
\end{abstract}

Keywords: Constructivist Approach, Attitude

\title{
I. INTRODUCTION
}

Constructivism is a theory that believes that human generates knowledge and understanding as a result of their ideas and experiences. It is founded on the premise that by reflecting on our experiences, we construct our own understanding of the world we live in. Constructivism is based on the belief that knowledge is not something that can be simply given by the teacher in the classroom. Rather, knowledge is constructed by learners through an active, mental process of development. Many studies have proven that children learn better when teachers used constructivist teaching. Studies conducted on students population have shown that the use of constructivist approach in classroom learning has greatly enhance the learning abilities among students and is very effective in terms of academic achievement and motivation, generating and retention of knowledge (Jong Suk Kim,2005; Watson, Aubusson, and Boddy ,2003; Artun, Huseyin, Costu\&Bayram ,2013). As children are actively involved in learning, there is a lot of collaboration and exchange of ideas between them and this makes learning more enjoyable. Students develop high order thinking skills as more thinking on their part is involved and are able transfer the new knowledge to real life.

The National Curriculum Framework (2005) in its aim of improving the children's natural desire to learn strongly support the use of Constructivist Approach in school education (Chapter 2.4.1Teaching for Construction of Knowledge) as this approach give importance to children's experiences, their voices and their active participation. Along the line of the recommendations of the NCF 2005, the NCTE brought out the National Curriculum Framework for Teacher Education in 2009. As a result, the teacher education programme was redesigned to focus on the learner, to provide a greater 'space' for personal, social and professional development of the teacher and to equip him/her to evolve pedagogic practices and create a learning environment that addresses the needs of learners (Mohapatra, Mohapatra\&Parida, 2015).

Even as this approach may have been used by individual teachers, majority of our teachers are still comfortable with using the traditional approach. As Constructivist Approach is a relatively new concept that has been incorporated only recently in the curriculum of teacher education courses across the country, adopting this approach in real classroom situations will be a very challenging task for the teachers. The only way to help them embrace this new approach is to change their attitude towards it.

Attitudes are expressions of how much we like or dislike various things. One of the reason that attitudes are important is that they are thought to guide behavior. A favourable attitude towards constructivist approach, on the part of the teacher will contribute towards the successful implementation of constructivist teaching in the classroom while an unfavourable attitude will hinder its application in classroom situations. Therefore, it is hoped that this present study will throw some light on the attitude of teachers towards constructivist approach in teaching. 


\section{Objective of The Study}

To study the level of Teacher's Attitude towards Constructivist Approach in Teaching.

\section{Hypothesis}

Ho1: There is no significant difference in the level of Teacher's Attitude towards Constructivist Approach in Teaching between Male and Female of DIETs

\section{Operational Definition of Terms Used}

1. Constructivist approach: -In this study, Constructivist approach is an approach that is used in teaching and involves components like (a) reflection; (b) learning process; (c) autonomycommunity; (d) authority facilitator; (e) power-empowerment and (f) evaluation.

2. Attitude: The attitude is a personal disposition which impels an individual to react to an object, situation or proposition in favorable or unfavorable ways.

\section{METHOD}

\section{Sample}

The tool was administered to 524 student teachers of District Institute of Education and Training (DIETs) .There are 7 DIETs in Meghalaya which are located in the 7 districts of the state i.e. Sohra, Nongpoh, Nongstoin, Thadlaskein, Baghmara, Tura and Resubelpera. DIETs have been set up in each of the seven districts of the State to offer a two year pre-service and in-service training to Elementary School Teachers

\section{Method}

The method used for the study is descriptive survey approach.

\section{Tool}

In order to find out the attitude of the teachers towards constructivist approach in teaching, the investigator had constructed and standardized the Teacher's Attitude Scale towards Constructivist Approach in Teaching (TASCAT). TASCAT consist of 40 items. The TASCAT is a Likert five point Summated Rating Scale. The categories of responses were 'strongly agree', 'agree', undecided', 'disagree', 'strongly disagree' and '4', '3', '2', ' 1 ', ' 0 ' were the scores for positive statements and the scores are in reverse order for negative statements. The Areas of the Scale has been divided into six components. Viz. (i) Reflection; (ii) Learning Process (iii) AutonomyCommunity (iv) Authority-Facilitator; (v) Power-Empowerment and (vi) Evaluation. The scale has face and content validity as the items initially framed were given to 20 experts for analyzing and editing the items of the scale. The reliability of the scale was computed by Karl Pearson's split half method. From the half test reliability coefficient, the whole test reliability coefficient was estimated by using Spearman Brown prophecy Formula and it was found to be 0.913.In addition, Cronbach Alpha was also calculated for finding out the internal consistency of the scale and the reliability was 0.907. The norms were also established for interpretation of obtained scores. This was done by converting the raw scores into percentile ranks.

\section{Statistical Analysis}

To find the mean difference between groups, ' $t$ ' test was used. 
IRA-International Journal of Education \& Multidisciplinary Studies

\section{III.FINDINGS OF THE STUDY}

The data collected from the samples was analyzedand the findings are shown below:

Table 1: Attitude of the student teachers towards Constructivist Approach

\begin{tabular}{|l|l|l|l|l|}
\hline $\begin{array}{l}\text { Sl. } \\
\text { No. }\end{array}$ & Raw Scores & Interpretation & N & \% \\
\hline 1 & 113 and above & Highly Favourable & 104 & 19.85 \\
\hline 2 & $107-112$ & Favourable & 106 & 20.23 \\
\hline 3 & $103-106$ & Moderate & 87 & 16.60 \\
\hline 4 & $97-105$ & Unfavourable & 117 & 22.33 \\
\hline 5 & 96 and below & Highly Unfavourable & 110 & 20.99 \\
\hline & & & 524 & \\
\hline
\end{tabular}

The above table shows the attitude of student teachers of DIETs of Meghalaya ( $=524)$ towards constructivist approach. It show that $22.33 \%$ of the entire sample have an unfavourable attitude and $20.99 \%$ have a highly unfavourable attitude while $20.23 \%$ have a favourable attitude .16 .60 have moderate attitude and $19.85 \%$ have a highly favourable attitude towards constructivist approach in teaching.

\section{Testing of Hypothesis}

Ho1- There is no significant difference in the level of Teacher's Attitude towards Constructivist Approach in Teaching between Male and Female of DIETs

Table2: Difference between Females and Males of DIETs

\begin{tabular}{|l|l|l|l|l|l|l|}
\hline Gender & $\mathbf{N}$ & Mean & $\boldsymbol{\sigma}$ & $\begin{array}{l}\text { Computed } \\
\text { 't' value }\end{array}$ & $\begin{array}{l}\text { Table 't' } \\
\text { value }\end{array}$ & Significance \\
\hline Female & 378 & 104.90 & 9.79 & 2.34 & 2.59 & $\begin{array}{l}\text { Not } \\
\text { Significant at } \\
\text {.01 level }\end{array}$ \\
\hline Male & 146 & 102.62 & 10.03 & 2.34 & & at \\
\hline
\end{tabular}

The result from the above table indicates that there is no significant difference in the level of Teacher's Attitude towards Constructivist Approach in Teaching between Males and Females. Therefore, the null hypothesis is accepted. It can be concluded that there is no significant difference in the attitude between male and female student teachers of DIETs towards constructivist approach in teaching.

\section{DISCUSSION}

Result shown in table 1 indicates that in general, a majority of the student teachers of DIETs $(22.33 \%)$ have an unfavourable attitude towards Constructivist Approach in Teaching. This implies that they are still in favour of traditional approach with the teacher as the authority in the classroom. This study is in line (more or less similar) with the findings of Taşkin-Can (2013) who found that, in general pre-service science teachers still hold teacher centred belief. In other words, they are still inclined towards traditional approach than constructivist approach.This study is in contrast to the findings of the study conducted by Uredi (2013); Hursen and Soykara (2012); Guha and Paul (2014) where it was found out that majority of the teachers have a positive attitude towards constructivist approach. The study shows that, in general, the student teachers of DIETs have an unfavourable attitude towards constructivist approach in teaching. This may be due to the fact that student 
teachers are products of a traditional system of education and cannot see themselves as applying another approach other than what they are being taught. As this approach has been only recently introduced in the curriculum of the teacher training institutes, they are yet to grasp its full implication in teaching situation. Moreover, teaching or learning or being aware about Constructivist Approach may not necessarily result in having a positive attitude towards it.

\section{CONCLUSION}

Changing the role of the teacher from the only authoritative source of knowledge to that of a guide and a facilitator will allow students to learn from their own experience which will surely make learning a more enjoyable experience thereby preventing students from leaving school mid-way. Even though shifting to Constructivist Approach may appear to be a challenging task, yet, with more awareness and knowledge about this approach, it is hoped that student teachers, teachers and teacher educators across the country will be more inclined towards this approach and hopefully will be able implement it in real classroom situations. As our attitudes are based on information, so the more information we gather about the attitude object (in this case about constructivist approach), there will be more possibilities for attitude change.

\section{References}

1. Artun,H.\&Costu, B.(2013).Effect of the 5E Model on Prospective Teachers' Conceptual Understanding of Diffusion and Osmosis: A Mixed Method Approach:Journal of Science Education and Technology, v22 n1 p1-10, Retrieved on 17.6.13 .fromhttp://www.eric.ed.gov/

2. Best,W.John\&Kahn,V.J..(2006).Research in Education. PHI Learning Private Limited, India

3. Boddy,N., Watson, K. \&Aubusson,P.(2013) A Trial of the Five Es: A Referent Model for Constructivist Teaching and Learning: Research in Science Education Vol 33,27-42, Kluwer Academic Publishers.

4. Brooks, J.G. \& Brooks, M.G. (1993). In search of understanding: The case of constructivist classrooms. Alexandria, V.A: Association for Supervision and Development.

5. Edwards,L.Allen..(1957). Techniques of Attitude Scale Construction. Prentice-Hall,Inc.,New Jersey

6. Guha,A.andPaul,U .(2014).Attitude towards Constructivist Approach and SelfEfficacy:Perspective of Secondary School Teachers:Indian Journal of Educational Research(Peer Reviewed), Volume III ,p 14-24,ISSN 2277-3819

7. Hursen, C., \&SoykaraA.(2012), Evaluation of Teachers' Beliefs Towards Constructivist Learning Practices: Procedia - Social and Behavioral Sciences Published by Elsevier Ltd.

8. Kim,.\&Suk.J.(2005).The Effects of a Constructivist Teaching Approach on Student Academic Achievement, Self-concept, and Learning Strategies: Education Review, Vol. 6, No. 1, 7-19 (2005)

9. Mohapatra,J.K,Mahapatra,M\&Parida, B.K..(2015). Constructivism The New Paradigm. Atlantic Publishers and Distributors, New Delhi

10. NCERT.(2005). National Curriculum framework-2005.Publishing department, New Delhi: NCERT. 
11. NCTE. (2009). National Curriculum Framework for Teacher Education 2009 -New Delhi: NCTE

12. Rainer,D.Julie..(2002).Reframing Teacher Education-Dimensions of Constructivist Approach. Kendall/Hunt Publishing Company,United States of America

13. Taşkin-Can,B..(2013).Perception of Turkish pre service science teachers concerning perspective to teach: Educational Research and Reviews, Vol 8(10),p613-619.Retrieved from http://www.academicjournals.org/err/abstracts/

14. Üredi,L.,(2013).The effect of classroom teachers' attitudes toward constructivist approach on their level of establishing a constructivist learning environment: A case of Mersin: Educational Research and Reviews, Vol. 8(11), pp. 668-676. 